\title{
Students' Errors in Learning Elementary Group Theory: A Case Study of Mathematics Students at Andalas University
}

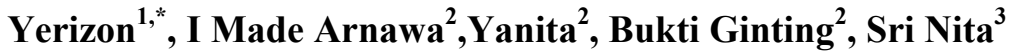 \\ ${ }^{1}$ Department of Mathematics, Universitas Negeri Padang, Padang, Indonesia \\ ${ }^{2}$ Department of Mathematics, Universitas Andalas, Padang, Indonesia \\ ${ }^{3}$ Electrical Department, Politeknik Negeri Padang, Padang, Indonesia
}

Received September 19, 2019; Revised November 1, 2019; Accepted November 8, 2019

Copyright $\mathrm{C} 2019$ by authors, all rights reserved. Authors agree that this article remains permanently open access under the terms of the Creative Commons Attribution License 4.0 International License

\begin{abstract}
This paper will discuss level of conceptual understanding of 18 mathematics students in learning elementary group theory during abstract algebra course 2016-2017 academic year at Andalas University. Participants were asked to answer three proof tests in relation to group theory. Students' solutions to the proof test were taken as the key source of data used to: (i) classify students to one of the four levels of conceptual understanding and (ii) analyze students errors in learning elementary group theory. One student for each level was interviewed to provide additional information about common students' errors on the proof task and to aid the process of understanding the underlying cause of these errors. The finding shows that: (1) Students' achievement in proof task is still problematic; (2) Most students have difficulties in verifying the existence of identity and inverse element; (3) Factors that contribute to errors in proof task are: lack of conceptual understanding and that student treated binary operations on a group as a binary operations on real numbers.
\end{abstract}

Keywords Students' Errors, Conceptual Understanding, Elementary Group Theory

\section{Introduction}

According to Baylis [1], proof is the heart of mathematics and thinking mathematically, so in evaluating the success of students in learning mathematics, especially in abstract algebra, should be assessed by the ability of the student in a proof task. Proof task makes mathematics unique and different from other disciplines [2], through the proof task, a lecturer can observe: (1) how the student's ability in arguing logically, (2) how students use examples or non-examples to support their argument, (3) what the weaknesses are experienced by students in reasoning, and (4) whatthe misconceptions that often experienced by college students are. Role of proof is very central in the pedagogy of mathematics without doubt, for example, Epp [3] stated that one of the most excellent aproachesto develop abstract thinking ability of the students is through meaningful involvement in constructing and completing mathematical proofs. Accordingto Findel [4], Proof proof plays an important role in abstract algebra, which is because abstract algebra is filled with definitions, lemmas, and theorems. In order to understand the abstract algebra, students are required to be able to understand every definition, lemma, theorem, and able to use them in proving some of the problems in abstract algebra.Thus, improving student understanding in abstract algebra can be done through improving the ability of students in proving, which is in line with what is suggested by Hanna [5] that the understanding in mathematics should be promoted through a mathematical proof. Learning mathematics without accompanied by a proof does not reflect the theory and practice of mathematics.

A mathematical proof on the college level is more formal and more accurate in comparison with proof in elementary schooland middle school [6], so most college students have difficulty in writing a mathematical proof, especially in abstract algebra, for example, see [7-10]. One contributing factor is a students' view against the proof, as stated by Down \& Down [11], namely that sometimes students look at formal proof as a game of manipulation of symbols that are not meaningful. Such a view ultimately make the students not understand the proof, even for a very simple proof.

In order to create a good mathematical proof, students 
are required to have a prerequisites knowledge, such as mathematical logic and methods of proof in mathematics. Having prerequisite knowledge does not guarantee that the students can develop and communicate a proof. According to Solow [12], to be able to develop and communicate a mathematical proof, students are required to have creativity, intuition, and experience. Having the intuition means having the ability to make a conjecture which is a very important part in the process of proof in mathematics. Just by intuition we can decide what we have to prove [13], having the creativity means having the ability to express the matter in various operational models [14]. According to Bloch [13], creativity, intuition, and experience can be developed through learning, as well as a musician that enhances his musical skills through learning/practice. Learning settings which provide opportunities to students to perform a wide range of representation and reflection can develop students' ability to prove [15]. The ability to prove is a slice of all abilities in mathematics which include understanding, reasoning, communication, representation, and problem solving. Those, in order to develop student ability to prove learning settings that could develop all the abilities in mathematics is needed.

The ability to prove in mathematics consists of skills in the construction of proof and the ability to validate (or criticize) the proof. Proof construction activities include the use of methods of proof, facts, concetps and principles in abstract algebra to show the truth of a statement, whereas activities in validating the proof consists of: (1) reading a proof in mathematics to determine the truth or fallacy by looking at the alignment of the premise, axiom, theorem or lemma with the groove of deductive reasoning, (2) completing the proof (if there was confusion), and (3) comparingthe effectiveness between the two proofs or more [16]. There were several ways to classify student ability to prove in abstract algebra. Hart [17] proposed four level conceptual understanding, namely: Level 0 (pre-understanding), level 1 (syntactic understanding), level 2 (concrete semantic understanding), level 3 (abstract semantic understanding).

What is the meaning of errors in mathematics? Although errors and misconceptions are related, they are different actually. An error is a mistake, slip, blunder, or inaccuracy and a deviation from accuracy [18]. A misconception, on the other hand, is the result of a lack of understanding or in many cases misapplication of a 'rule' or mathematical generalization [19], A misconception happens when a person believes in a concept that is objectively false [20], and an error might be caused due to a misconception [21].
One of the ways used to analyze students'errors is categorizing them into a certain characterization based on an analysis of students' behavior. Errors that student had in attempt to prove in group were classified into five categories, namely: (i) unable to verify closed axiom (E1); (ii) unable to verify associative axiom (E2); (iii) unable to verify the existence of element identity (3); (iv) unable to verify the existence of inverse element (E4); (v) unable to use commutative property (E5),

Group theory is the basic concept that makes up ring and field in abstract algebra, so that weaknesses in understanding ring and field can be traced through weaknesses in understanding group theory. Research on proof ability in group theory has been done a lot, for example, see [8-10] and [22], but none of them specifically examined group axioms. The definitions about group, commutative group, and the power of an element in a group are stated in table 1.

Tabel 1.The definition about group, commutative group and the power of an element in a group

Definition $1[23]$
Let $\mathrm{G}$ be a non-empty set, $\mathrm{G}$ is said to form a group if in $\mathrm{G}$ there is a
defined binary operation, denoted $b y *$ such that $(1)$.If $\mathrm{a}, \mathrm{b} \in \mathrm{G}$
then $\mathrm{a} * \mathrm{y} \in \mathrm{G},(2)$. If $\mathrm{a}, \mathrm{b}, \mathrm{c} \in \mathrm{G}$ then $\mathrm{a} *(\mathrm{~b} * \mathrm{c})=(\mathrm{a} * \mathrm{~b}) * \mathrm{c},(3)$. There
exists an element $\mathrm{e} \in \mathrm{G}$ such $\mathrm{a} * \mathrm{e}=\mathrm{e} * \mathrm{a}=\mathrm{a}$ for all $\mathrm{a} \in \mathrm{G},(4)$. If $\mathrm{a} \in$
$\mathrm{G}$ there exists $\mathrm{b} \in \mathrm{G}$ such that $\mathrm{a} * \mathrm{~b}=\mathrm{b} * \mathrm{a}=\mathrm{e}$.
Definition 2 [23]
Let $(\mathrm{G}, *)$ be a group, $\mathrm{G}$ is said to be commutative if for every a,b
$\in \mathrm{G}, \mathrm{a} * \mathrm{~b}=\mathrm{b} * \mathrm{a}$.
Definition 3 [23-24]
Let $(\mathrm{G}, *)$ is a group, a $\in \mathrm{G}$, and $\mathrm{n} \in \mathbb{Z}$. We define $(1) \mathrm{a}^{\mathrm{n}}=\mathrm{e}$, when
$\mathrm{n}$ is $\mathbf{0},(2) \mathrm{a}^{\mathrm{n}}=\mathrm{a} * \mathrm{a} * \mathrm{a} \ldots * \mathrm{a}$ ( $\mathrm{n}$ factors) when $\mathrm{n}$ is positive, (3) $\mathrm{a}^{\mathrm{n}}=$
$\mathrm{a}^{-1} * \mathrm{a}^{-1} * \mathrm{a}^{-1} \ldots * \mathrm{a}^{-1}$ (n factors) when $\mathrm{n}$ is negative.

\section{Materials and Methods}

The aim of this research was to analyze the process and errors that students peform as they attempt to write proofs in group theory. Subjects were 18 mathematics students who took abstract algebra course during short semester the 2016/2017 academic year at Andalas University. The main instrument was the proof test, which consisted of three proof tests. Criteria used in the development of the proof test were: (1) the conceptual test would focus on group theory, (2) it was designed to cover all level of proofs ability [17]. The first draft of the proof test was given to two lecturers of Abstract algebra at Andalas University. These lecturers were asked to comment on the standard of questions in proof test and on the clarity of the questions. The final proof test of this study is listed in table 2 . 
Table 2.Proof Test for Group Theory

\begin{tabular}{|c|c|}
\hline Code & Question \\
\hline PT1 & Let $(\mathrm{G}, *)$ be a commutative group. For all $\mathrm{a}, \mathrm{b} \in \mathrm{G}$,and $\mathrm{n} \in \mathbb{Z}$, which show sthat $(\mathrm{a} * \mathrm{~b})^{\mathrm{n}}=\mathrm{a}^{\mathrm{n}} * \mathrm{~b}^{\mathrm{n}}$ \\
\hline PT2 & Let $\mathrm{G}=\left\{\left(\begin{array}{rr}\mathrm{a} & 0 \\
0 & \mathrm{~d}\end{array}\right) \mid \mathrm{a}, \mathrm{d} \in \mathrm{R}, \mathrm{a} . \mathrm{d}=1\right\}$. Show that $\mathrm{G}$ is a group under the multiplication of matrices \\
\hline PT3 & $\begin{array}{l}\text { Let }(\mathrm{G}, *) \text { be a commutative group and } \mathrm{t} \in \mathrm{G}, \text { we define a new binary operation in } \mathrm{G} \text { denoted by } \Delta \text { such that for all a,b } \in \mathrm{G}, \\
\mathrm{a} \Delta \mathrm{b}=\mathrm{a} * \mathrm{~b} * \mathrm{t} \text {. Show that } \mathrm{G} \text { is a group under the binary operation } \Delta\end{array}$ \\
\hline
\end{tabular}

Each proof was graded on a scale of 0 to 4 as follows: 0 (non commencement); 1 (approach made); 2 (substantial progress); 3 (result achieved with only minor errors); 4 (completion). Based on the correctness (score 3 or 4 ) of their solution to proofs, students were classified into one of four levels of conceptual understanding as follows: (1) level 0 (none of the three proofs were correct); (2) level 1 (proof 1 was correct, but proofs 2 and 3 were incorrect); level 2 (proofs 1 and 2 were correct, but proof 3 was incorrect); level 3 (all three proofs were correct). Students that did not fit to one of the levels were classified as non fitters (NF) [17]. Selected students for each level were interviewed, the aim of the interview was to provide additional information about common student difficulties on the proofs task and to aid the process of understanding the underlying cause of these errors.

\section{Results and Discussion}

The mean scores for each questions and for each levels are presented at table 3.

Table 3.Mean scores on the proof test

\begin{tabular}{|c|c|c|c|c|c|c|}
\hline & $\begin{array}{c}\text { Level 0 } \\
(\mathrm{n}=2)\end{array}$ & $\begin{array}{c}\text { Level 1 } \\
(\mathrm{n}=2)\end{array}$ & $\begin{array}{c}\text { Level 2 } \\
(\mathrm{n}=10)\end{array}$ & $\begin{array}{c}\text { Level 3 } \\
(\mathrm{n}=3)\end{array}$ & $\begin{array}{c}\text { Non-Fitter } \\
(\mathrm{n}=1)\end{array}$ & $\begin{array}{c}\text { Over all levels } \\
(\mathrm{n}=18)\end{array}$ \\
\hline PT1 & 1.5 & 3.0 & 3.0 & 4.0 & 0.0 & 2.83 \\
\hline PT2 & 1.0 & 2.0 & 3.7 & 4.0 & 3.0 & 3.22 \\
\hline PT3 & 0.0 & 1.0 & 3.0 & 3.33 & 3.0 & 2.5 \\
\hline All PT & 0.83 & 2.0 & 3.23 & 3.66 & 2.0 & 2.83 \\
\hline
\end{tabular}

There are several things that can be observed from table 2, namely: (1) mean score over all levels and over all proofs test i.e. 2.83 is far below the maximum score 4; (2) based on the means score over all levels, PT2 is the easiest proofs, while the most difficult is PT3, (3) only one of three proofs i.e. PT2 was the mean score over all levels up to minimum correct score of 3 . Errors that student had in attempt to prove in elementary group theory, at each level are presented at table 4 .

Table 4.Errors Distribution on Each Levels

\begin{tabular}{|c|c|c|c|c|}
\hline & Level 0 & Level 1 & Level 2 & Level 3 \\
\hline E1 & $\sqrt{ }$ & & & \\
\hline E2 & $\sqrt{ }$ & $\sqrt{ }$ & $\sqrt{ }$ \\
\hline E2 & $\sqrt{ }$ & $\sqrt{ }$ & $\sqrt{ }$ \\
\hline E4 & $\sqrt{ }$ & $\sqrt{ }$ & $\sqrt{ }$ \\
\hline E5 & $\sqrt{ }$ & & & \\
\hline
\end{tabular}


Table 4 shows that most students had difficulties in verifying the existence of element identity (E2) the existence of inverses element (E4). Some of the interesting errors that students had in attempt to prove in elementary group theory are reported here.

1. For proof test PT1, only 3 of 18 student can prove right. A common error was less careful ininterpreting $\mathrm{n} \in \mathbb{Z}$, i.e., $\mathrm{n}=0, \mathrm{n}>0$, and $\mathrm{n}<0$. Most of student answered as follows.

$(a * b)^{\mathrm{n}}=(\mathrm{a} * \mathrm{~b}) *(\mathrm{a} * \mathrm{~b}) * \ldots *(\mathrm{a} * \mathrm{~b})$

(n factors of $(\mathrm{a} * \mathrm{~b}))$

$=a *(b * a) *(b * a) * \ldots . . *(b * a) * b$

( $\mathrm{G}$ is associative)

$=\mathrm{a} *(\mathrm{a} * \mathrm{~b}) *(\mathrm{a} * \mathrm{~b}) * \ldots . . *(\mathrm{a} * \mathrm{~b}) * \mathrm{~b}$

$((\mathrm{G}, *)$ is a commutative group)

$=a * a *(b * a) * \ldots . . *(b * a) * b * b$

$((\mathrm{G}, *)$ is a commutative group)

$=(a * a \ldots * a) *(b * b * \ldots . . b)=a^{n} * b^{n}$

But this is only for $\mathrm{n}>0$, while for $\mathrm{n}=0$ and $\mathrm{n}<0$, not yet proven.

2. For proof test PT2, only 4 of 18 student can not prove well. For example, IBL is one of 4 student that had difficulty in determining the inverse of an element in $\mathrm{G}$, IBL wrote as follows.

Let $\mathrm{x}=\left(\begin{array}{cc}a_{1} & 0 \\ 0 & d_{1}\end{array}\right) \in \mathrm{G}$ and $\mathrm{y}$ is an inverse of $\mathrm{x}$ then

$x . y=\left(\begin{array}{ll}1 & 0 \\ 0 & 1\end{array}\right)$, so

$y=\left(\begin{array}{ll}1 & 0 \\ 0 & 1\end{array}\right) /\left(\begin{array}{cc}a_{1} & 0 \\ 0 & d_{1}\end{array}\right)=\left(\begin{array}{cc}1 / a_{1} & 0 \\ 0 & 1 / d_{1}\end{array}\right)$

3. For proof test PT3, only 4 of 18 student can prove well (score 3 or 4). A common error was the difficulty in determining the inverse and identity element in G. For example, RMD is one of 14 students that had difficulty in determining identity element and the inverse of an element in G, RMD wrote as follows.

Let $\mathrm{a} \in \mathrm{G}$ and $\mathrm{e}$ is identity element in $\mathrm{G}$, then $\mathrm{a} \Delta \mathrm{e}=\mathrm{a}$ or $\mathrm{a} * \mathrm{e} * \mathrm{t}=\mathrm{a}$, so $\mathrm{e}=1 / \mathrm{t}$,

Let $a \in G$ and $b$ is an inverse of $a$, then

$\mathrm{a} \Delta \mathrm{b}=1 / \mathrm{t}$ or $\mathrm{a} * \mathrm{~b} * \mathrm{t}=1 / \mathrm{t}$, so $\mathrm{b}=1 / \mathrm{at}^{2}$.

The results of the interview revealed that there are some factors that cause an error in proof task, the interviewee was GLG (level 0), ANS (level 1), IBL (level 2) and RMD (level 3), the extract of the interview between researcher (RSH) and students as follows.
$R S H:$ what does it mean by $(G, *)$ is a group? GLG: hmm..., G is closed, $G$ is associative, $G$ has element identity, and every element in $G$ has inverses element.

RSH: Can you write down it in mathematical symbol?

GLG: Sorry sir, I am not sure.

$R S H$ : $A N S$, in group $(G, *)$, what does it mean by

$a^{n}, a \in G$, and $n \in \mathbb{Z}$ ?

ANS: hmm..., $a^{n}=a * a * a \ldots * a$

(n factors of a)

RSH: $n \in \mathbb{Z}$, how about $n<0$ ?

Is it $a^{n}=a * a * a \ldots * a$ ?

ANS: I think yes

RSH: You have to look back the definition

of $a^{n}$ in group theory.

$R S H: R M D, R-\{0\}$ is a group under

multiplication? isn't it?

RMD: hmm..., yes

RSH: now, if $a, b \in R-\{0\}$ and $a . b=1$,

can you solve for $b$ ?

RMD: yes, $b=1 / a$.

$R S H$ : In general, if $(G, *)$ is a group, a,e,t $\in G$

and $a * e * t=x$ can you solve for $e$ ?

$R M D$ : I think yes, $e=1 / t$.

$R S H$ : What do you mean by e $=1 / t$ ?

1 divided by $t$ ?

RMD: Yes, Sir.

RSH: is it lalways in G?

RMD: No, Sir.

RSH: If so, how should solve for e?,

try it in intens minutes!

After tens minutes, RMD shows what he is doing as follows.

$\mathrm{a} * \mathrm{e} * \mathrm{t}=\mathrm{a}$

$\mathrm{a}^{-1} *(\mathrm{a} * \mathrm{e} * \mathrm{t})=\mathrm{a}^{-1} * \mathrm{a}($ all element in $\mathrm{G}$ has an inverse $)$

$\left(a^{-1} * a\right) * e * t=e(G$ is associative $)$

$e_{*} e_{*} t=e$

$e_{*} t=e(e$ element identity in $G)$

$(\mathrm{e} * \mathrm{t}) * \mathrm{t}^{-1}=\mathrm{e}_{*} * \mathrm{t}^{-1}$

$e *\left(t * t^{-1}\right)=t^{-1}$

$\mathrm{e}=\mathrm{t}^{-1}$

Based on the analysis of the students' answer sheets in proof task and the results of interviews, the main causes of the errors were: (1) students lack conceptual understanding in elementary group theory and (2) students treat binary operations on a group as a binary operations on real numbers. The cause of the first error, namely "students lack conceptual understanding" is a common error in mathematics problem solving. There are many research results about this, for example, see [25], according to Agustyaningrum, Abadi, Sari \& Mahmudi [25], most of the 
students' errors were on conceptual understanding,while the cause of the second major errors was in line with the results of the research that has been discovered by the researchers, i.e. Selden \& Selden [7], list thirteen types of errors in college level theorem proving that one of these errors is the rules that students know for dealing with real numbers and is universal.There are many ways to minimize students' difficulties in group theory, such as by choosing a learning approach (forms of pedagogy) [26], especially learning approach that allows students to become critical thinkers [27], for example, the use of APOS theory approach can minimize students' difficulties in learning system of linear equation [28]. In APOS theory, students work in a group of three or more peers to conduct an intimate discussion of a mathematical topic,so they can minimize their difficulties in learning mathematics and finally can improve student interest in learning mathematics [29].

\section{Conclusions}

Based on the data analysis, we have some conclusions: (1). Students' achievement in proof task is still problematic; (2). Most students have difficulties inverifying the existence of identity element and the existence of inverses element, (3). Factors that contribute to errors in proof task are: lack of conceptual understanding and students treat binary operations on a group as a binary operations on real numbers.

\section{Acknowledgements}

This research was supported by The Ministry of Research, Technology and Higher Education in accordance with the research contract number 051/SP2H/LT/DRPM/2019, fiscal year 2019.

\section{REFERENCES}

[1] J. Baylis. Proof-Essence of Mathematics. International Journal of Mathematics Educations and Science Technology, 14, 409-414, 1983.

[2] D. Reid. Proofs, Proving and Probing: Research Related to Proof. Unpublished paper on the Twenty-Fifth Annual Conference of the International Group for the Psychology of Mathematics Education. Utrecht, Netherlands, 2001.

[3] S. Epp. The Role of Logic in Teaching Proof. The American Mathematical Monthly, 106(1), 886-889, 2003.

[4] B.R. Findel. Learning and Understanding in Abstract Algebra. Unpublished Doctoral Dissertations. Concord: New Hampire University, 2001.

[5] G. Hanna. A Critical Examination of Three Factor in The
Decline of Proof. Interchange, 31(1), 21-23, 2000.

[6] P.Y. Lee. What Do We Do With School Geometry. Unpublished paper on Conference on Recent Progress in Mathematics Education. ITB Bandung Indonesia, 2004.

[7] A. Selden \& J. Selden. Errors and Misconception in College Level Theorem Proving. Technical Report at Department of Mathematics Tennessee Technological University. Cookeville USA, 2003a.

[8] I.M. Arnawa. Mengembangkan Kualitas Pemahaman dalam Aljabar Abstrak melalui Pembelajaran Berdasarkan Teori APOS (Eksperimen pada Mahasiswa Matematika UNAND dan Pendidikan Matematika UNP). Jurnal Pendidikan dan kebudayaan Balitbang Depdiknas, 13(068), 2007.

[9] I. M. Arnawa, U. Sumarmo, B. Kartasasmita \& E. Tribaskoro. Applying the APOS theory to improve student's ability to prove in Elementary Abstract Algebra. Journal of the Indonesian Mathematical Society, 13(1), 2007.

[10] I. M. Arnawa. Mengembangkan Kemampuan Mahasiswa dalam Memvalidasi Bukti pada Aljabar Abstrak melalui Pembelajaran yang berdasarkan Teori APOS. Jurnal Matematika \& sains, 14(2), 2009.

[11] M. J. Down \& M. Down. Advanced Mathematics Thinking with a Special reference to Reflection on Mathematics Structure. In L.D. English (Ed.). Handbook of International Research in Mathematics Education. Mahwah NJ: Lawrence Erlbaum Associate, 2002.

[12] D. Solow, D. (1990). How to Read and Do Proof. Cleveland: John Willey and Sons, 1990.

[13] E.D. Bloch. Proof and Fundamental: A First Course in Abstract Algebra mathematics. Boston: Birkhauser, 2000.

[14] G. Ervynck. Mathematical Creativity. In D. Tall (Ed.). Advanced Mathematical Thinking. Dordrecht: kluwer Academic Publishers, 1991.

[15] C. Maher \&A. Martino, A. The Development of the Idea of Mathematical Proof: A 5-Year Case Study. Journal for Research in Mathematics Education, 7(2), 194-214, 1996.

[16] A. Selden \& J. Selden. Validations of Proof as Texts: Can Undergraduate Tell Whether an Argument Prove a Theorem?. Journal for Research in Mathematics Education, 34(1), 4-36, 2003.

[17] E.W. Hart. A Conceptual Analysis of the Proof-Writing Performance of Expert and Novice Students in Elementary Group Theory. In J.J. Kaput \& Ed Dubinsky (Ed.). Research Issues in Undergraduate Mathematics Learning. Washington: The Mathematical Association of America, 1994.

[18] K. Luneta\& P. J. Makonye. Learners Errors and Misconceptions in Elementary Analysis: A Case Study of A Grade 12 Class in South Africa. Acta Didactica Napocencia. 3(3), 2010.

[19] M. Spooner. Errors and Misconceptions in Maths at Key Stage 2. London: David Fulton, 2003.

[20] J. Muzangwa\& P. Chifamba. Analysis of Errors and Misconceptions in the Learning of Calculus by Undergraduate Students. Acta Didactica Napocencia. 5(2), 
2012.

[21] R. G. Mohyuddin \& U. Khalil. Misconceptions of Students in Learning Mathematics at primary Level. Bulletin of Education and Research. 31(1):133-162, 2016.

[22] E.E. Arikan, A. Ozkan\& E.M. Ozkan. An examination in Turkey: Error analysis of Mathematics students on group theory. Educational Research and Reviews, 10(16), 2352-2361, 2015.

[23] I. N. Herstein. Topics in Algebra. 2th Ed. New York: John Willey and Sons, 2000.

[24] J. A. Galian.Contemporary Abstract Algebra. 4th Ed. New York: Hougton Mifflin Company, 1998.

[25] N. Agustyaningrum, A. M. Abadi, R. N. Sari \& A. Mahmudi. An Analysis of Students' Error in Solving Abstract Algebra Tasks. Journal of PhysicsConf. Series, 1097, 012118, 2018.

[26] K. Weber\&S. Larsen. Teaching and Learning Group Theory. In M. Carlson \& C. Rasmussen (Eds.).Making the Connection: Research and Teaching in Undergraduate Mathematics Education, 139-152. Mathematical Association of America, 2008.

[27] A.F. Westbrook. A Case Study of How Ninth Grade Mathematics Students Construct Knowledge during a Productive Failure Model. Georgia Educational Research Association Conference.63, 2014. Online available http://digitalcommons.georgiasouthern.edu/gera/2014/201 $4 / 63$.

[28] I. M. Arnawa, Yerizon, S. Nita \& R. T. Putra. Development of Students' Worksheet Based on APOS Theory Approach to Improve Student Achievment in Learning System of Linear Equations. International Journal of Scientific \& Technology Research, 8(04), 287-292, 2019.

[29] S.G. Krantz.How to Teach Mathematics Third Edition. Providence, Rhode Island: American Mathematical Society, 2015. 